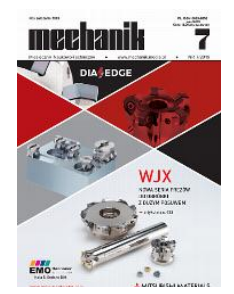

How to cite this article:

Authors: Kamil Cieplak, Tomasz Majewski

Title of article: „Investigations of hollow sphere structures produced by selective laser sintering”

Mechanik, No. 7 (2019)

DOI: https://doi.org/10.17814/mechanik.2019.7.50

\title{
Investigations of hollow sphere structures produced by selective laser sintering
}

\author{
KAMIL CIEPLAK \\ TOMASZ MAJEWSKI *
}

\begin{abstract}
Mgr inż. Kamil Cieplak, kamil.cieplak@wat.edu.pl, https://orcid.org/0000-0002-0825-2689 - Wydział Mechatroniki i Lotnictwa, Wojskowa Akademia Techniczna, Warszawa, Polska

Dr hab. inż. Tomasz Majewski, tomasz.majewski@wat.edu.pl, https://orcid.org/0000-0003-2850-1205 - Wydział Mechatroniki i Lotnictwa, Wojskowa Akademia Techniczna, Warszawa, Polska
\end{abstract}

The research of hollow sphere structures as absorbers of mechanical energy is described. The first part of the article is devoted to the description of selective laser sintering additive technique as the optimal method of sample production in the case of laboratory tests. The next part presents the use of computer aided design to create parametric three-dimensional models. Next, the results of experimental tests in the conditions of quasi-static load are presented. Based on the collected data, a qualitative analysis of the structure deformation process was performed and final conclusions are presented.

KEYWORDS: machine design and maintenance, cellular materials, selective laser sintering

\section{Introduction}

The paper is a continuation of work related to the research on three-dimensional structures with a topology called the hollow sphere (in short: HS). Based on this topology, one can design many variants of structures, differing among others, the way of placing cells in the whole volume of the structure, the size of cells or the thickness of their walls.

Further work focused on determining the significance of cell size and wall thickness, which directly determines the obtained relative density of the material. The use of incremental techniques to pre-test the mechanical properties of different variants of structures is a common practice [1]. Additive techniques allow for the production of samples with repeatable strength parameters.

Unfortunately, most of the systems offered on the market introduce limitations in terms of the choice of materials and technologically determined geometric parameters. Another difficulty is the inability to obtain a structure with closed and hollow pores. Therefore, the tested samples contain support material enclosed within the pores. To avoid this disadvantage, one need to modify the geometry by introducing technological holes to empty the interior of the cells.

In the first case, the influence of supporting material in cells on the obtained mechanical energy absorption characteristics should be considered. It is also difficult to unequivocally determine the correctness of sample preparation if the evaluation criterion is a comparison of the obtained mass with the mass determined, e.g. in a computer-aided design program. If technological holes are introduced, it is expected that the mechanical strength of the cellular material will decrease.

\section{Selective laser sintering (SLS) method}

The Faculty of Mechatronics and Aviation of the Military University of Technology has a Sinterit Lisa printer using the selective laser sintering (SLS) method. This method involves sintering of polymer powders, including PA12 polyamide with the addition of carbon, by means of a powerful energy source in the form of a laser beam. The powder inside the machine is moved by means of a scraping system from the space of the supply bed to the bed, in which the printout is made. One layer is applied in a single measure. 
Depending on the construction of the machine, there are several methods for moving the laser beam directed to the print surface. In the first case, the beam travels independently to the laser source, using an optical system (fig. 1). This solution allows for the use of more than one source of laser beam directed by a mirror system. In the second case, the system consisting, among others, from the laser diode, lens and cooling system, is on the trolley like in 2D plotters. This solution is mainly used in small systems that do not require high accuracy. Most of the material (approximately 70\%) from the previous process is reused [3] after screening the contaminants formed during the sintering process.

Both material used for testing and the software were provided by the printer manufacturer. In order to obtain repeatability of experiments, all samples were made in the same orientation and with identical printing parameters, including layer height of $0.15 \mathrm{~mm}$. As part of the verification, a material sample was made for each print series in accordance with ISO 527 [4].

Based on the results of the static tensile test for subsequent batches of samples, a Young's modulus of $0.613 \pm 0.038 \mathrm{GPa}$ and strain at failure of $0.138 \pm 0.002 \mathrm{~mm} / \mathrm{mm}$ were recorded. The obtained values of the bursting force and strain of the sample prepared in the initial tests may result from the modification of the SLS printer operating system introduced during the tests.

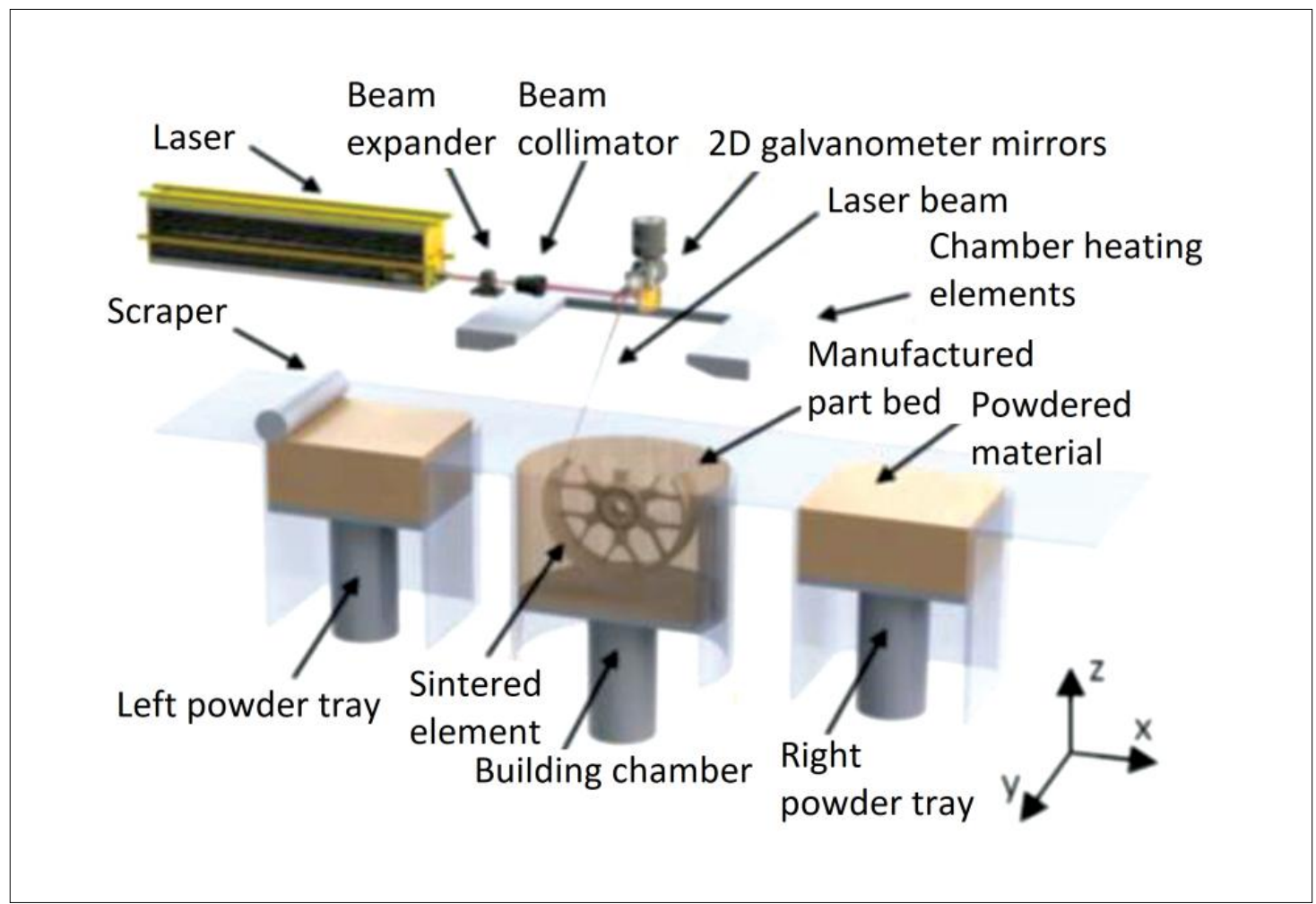

Fig. 1. Operation diagram of the SLS printer [2]

\section{Parameterization of the three-dimensional HS structure model}

Computer-aided design programs enable performance of parametric three-dimensional models. This allows to significantly reduce the time to generate three-dimensional models and eliminates the introduction of errors during modeling.

Making a parametric model requires determining the geometrical quantities that will be modified and their impact on other parameters. Using the equation editor, one can create variables and give them unambiguous names, which are then used to define model geometry, including parameter denoting cell wall thickness and describing the cell diameter. Then the variables defining other geometrical dimensions are presented using the ones already defined. The final shape of the sample model is adjusted for dynamic testing using a Split Hopkinson Pressure Bar (SHPB).

The use of samples with similar geometric dimensions in static and dynamic experiments allowed for a qualitative comparison of the results obtained. It was assumed that in the case of tests carried out at the SHPB stand, their size may not exceed the diameter of the rod used, which is $36 \mathrm{~mm}$.

As part of the study, two parametric HS models were made with closed pores and technological holes used. The shape of a single cell in the variant with open cells is shown in fig. 2. 


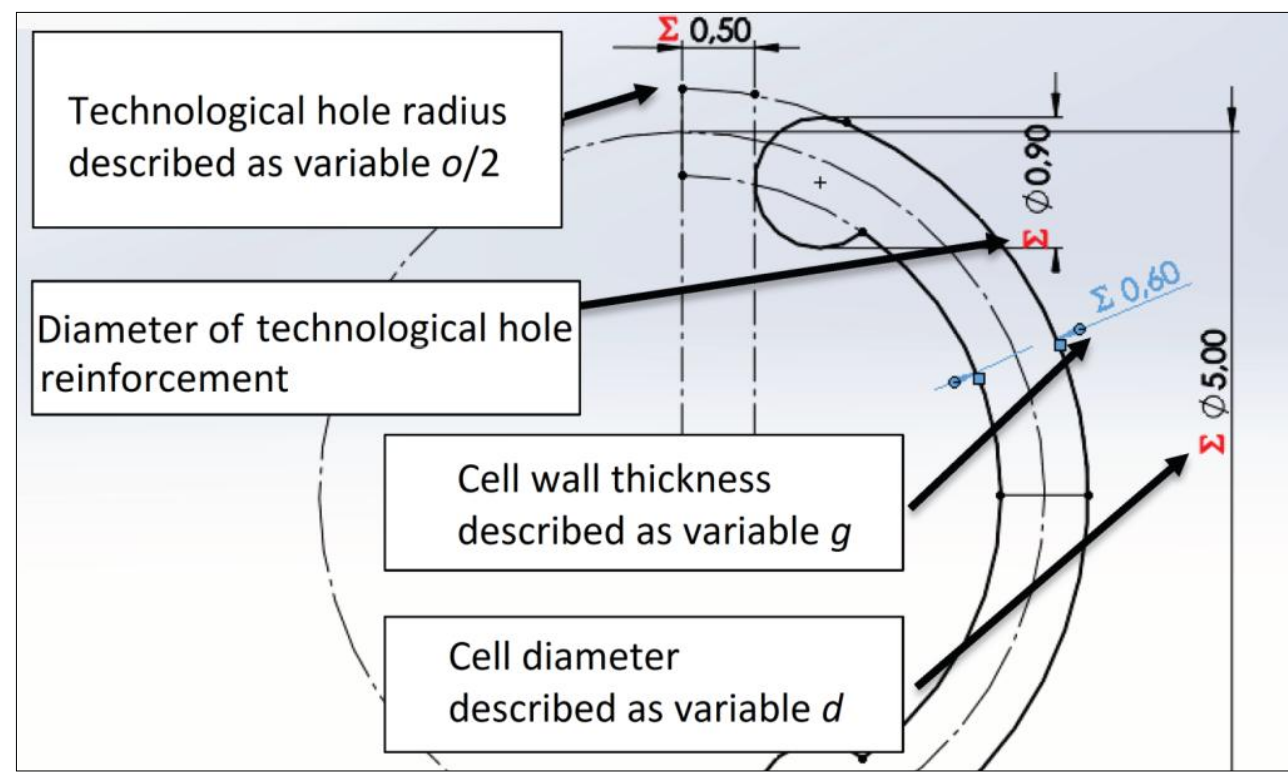

Fig. 2. Sketch of the HS cell with technological holes

\section{Experimental studies on mechanical properties of HS structures}

The MTS Criterion Model 45 machine was used for the static compression test. The tests were carried out for a traverse speed of $1 \mathrm{~mm} / \mathrm{s}$.

In the initial tests, square-base samples were used to determine the effect of wall thickness on mechanical energy absorption. Obtained force courses as a function of relative shortening for a wall thickness of $0.3 \mathrm{~mm}$, $0.4 \mathrm{~mm}$ and $0.5 \mathrm{~mm}$ are shown in fig. 3 .

One can notice a clear influence of geometrical parameters of samples on the recorded force waveforms. The nature of the curves obtained is similar to that of materials considered as energy-consuming, as shown in fig. 4 [5]. The obtained values were converted into energy values as a function of relative shortening and are presented in fig. 5 .

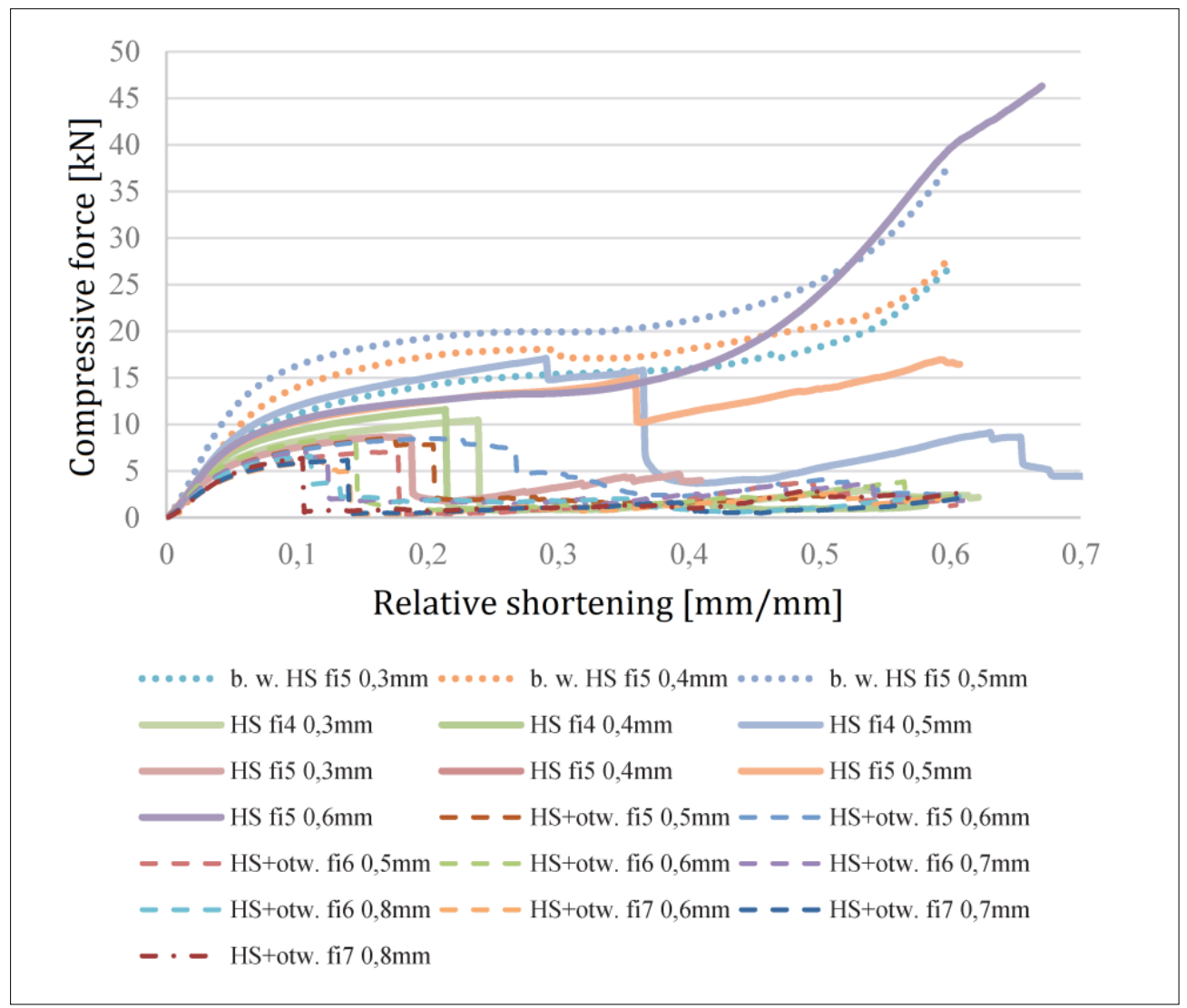

Fig. 3. Collective graph of force dependency as a function of relative shortening obtained from tests: preliminary tests HS, basic test HS and HS with holes 


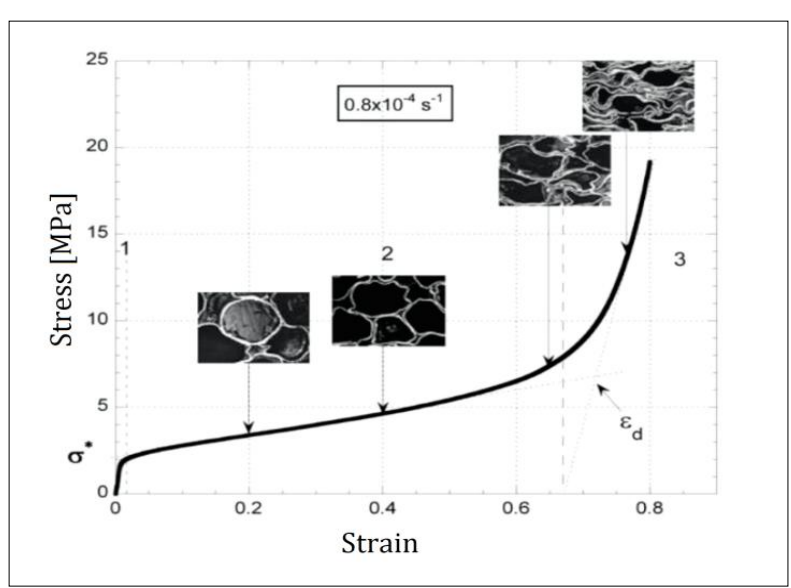

Fig. 4. Stress-strain quasi-static curve for HS [5]

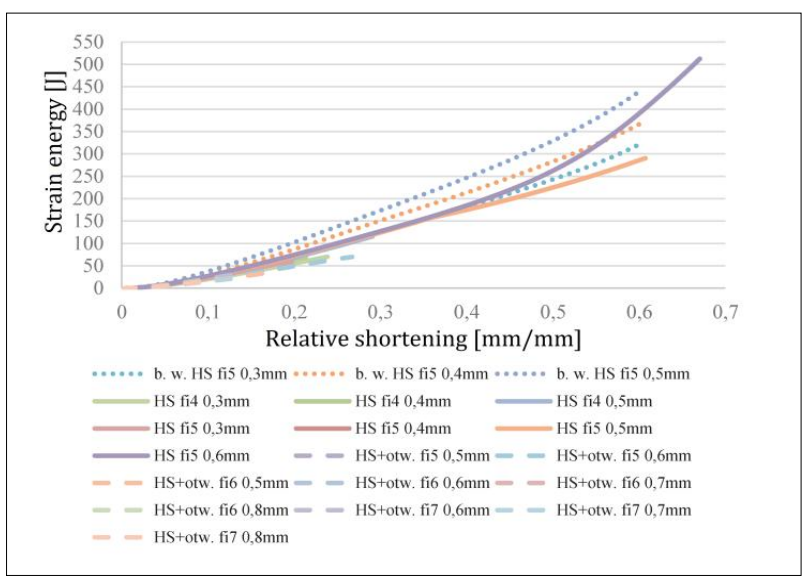

Fig. 5. Collective graph of the strain energy dependence on the relative shortening function obtained from the tests: preliminary tests HS, basic test HS and HS with holes

\section{Analysis of results}

Results of tests carried out for the final geometry of samples, to a small extent correspond with results of preliminary tests. The small number of cells in the cross-section had a large impact on this, which is probably the main reason for the sample destruction at the time of transition from the elastic range to the collapse of the structure. Reduction in the cell size is not possible due to technological limitations.

Qualitative assessment of the obtained waveforms shows that structures with small cells and a thick cell wall (higher relative density) allow for the absorption of more energy. Visible deterioration of mechanical properties of the structure modified by technological holes introduced, manifested in the destruction of the structure after exceeding the elastic range.

The best results using this material are observed for the HS variant with a cell size of approximately $5 \mathrm{~mm}$ and a wall thickness of about $0.6 \mathrm{~mm}$, i.e. for relative density of approximately $30 \%$.

\section{Summary}

Performance of the parametric model allowed for obtaining geometry in a shorter time, and additionally prevented from errors in the design process of subsequent variants. The additive technique, which is SLS, has made it possible to make many variants of samples with very similar material parameters.

The research concluded that a material with greater elasticity should be used in subsequent experiments than the one described for PA12 polyamide with the addition of carbon. Quasi-static tests of sintered materials and structures must be repeated. Differences in the maximum strength values between the modified (by adding technological holes) and unmodified structure may be due to the presence of powder inside the closed cells.

Performing dynamic tests on SHPB will be justified if the tested structures show the properties of energyconsuming materials. In the course of further work, structural variants with relative density of not less than $30 \%$, should be considered primarily.

\section{The paper contains results of the work financed by WML WAT from funds for science in the years 2018-2019, as research project No. RMN/951/2018.}

\section{REFERENCES}

[1] Płatek P., Baranowski P., Cieplak K., Sarzyński M., Sienkiewicz J., Janiszewski J., Małachowski J. "Investigation on deformation process of cellular structures with gradient topology manufactured additively". AIP Conference Proceedings. (2018) 020108-1, https://doi.org/10.1063/1.5092111.

[2] Kleijnena R.G., Sesseg J.P.W., Schmid M., Wegener K. "Insights into the development of a short-fiber reinforced polypropylene for laser sintering”. AIP Conference Proceedings. (2017) 190002-2, https://doi.org/10.1063/1.5016791.

[3] www.sinterit.com/wp-content/uploads/2014/05/PA12-Specification.pdf (access: 1.04.2019 r.).

[4] PN-ISO 527-2:2012 - Tworzywa sztuczne - Oznaczanie właściwości mechanicznych przy statycznym rozciąganiu - Część 2: Warunki badań tworzyw sztucznych przeznaczonych do różnych technik formowania.

[5] Taşdemirci A., Ergönenç Ç., Güden M. "Split Hopkinson pressure bar multiple reloading and modeling of a 316 L stainless steel metallic hollow sphere structure”. International Journal of Impact Engineering. 37 (2010): 250-259, https://doi.org/10.1016/i.ijimpeng.2009.06.010. 